\title{
Simple Reason for Hypoglycemia: ACE Inhibitor-induced Severe Recurrent Hypoglycemia in a Nondiabetic Patient
}

\author{
Ghada Elshimy ${ }^{1}$, Pawarid Techathaveewat ${ }^{1}$, Mahmoud Alsayed ${ }^{1}$, Sathya Jyothinagaram ${ }^{1}$, \\ Ricardo Correa ${ }^{1}$ \\ 1. Endocrinology, Diabetes and Metabolism, University of Arizona College of Medicine-Phoenix, \\ Phoenix, USA
}

$\square$ Corresponding author: Ghada Elshimy, ghada_elchimi@hotmail.com Disclosures can be found in Additional Information at the end of the article

\section{Abstract}

Angiotensin-converting enzyme (ACE) inhibitors are among the most common medications used to treat patients with concomitant diabetes and hypertension. They are considered the first line of treatment for hypertension in this population. Several case studies have reported that ACE inhibitors can induce hypoglycemia in patients with diabetes. To our knowledge, however, ACE inhibitors have not been found to induce hypoglycemia in patients without diabetes. This report describes a patient without diabetes experiencing recurrent severe hypoglycemia induced by the ACE inhibitor lisinopril.

Categories: Endocrinology/Diabetes/Metabolism, Internal Medicine, Miscellaneous Keywords: lisinopril, ace inhibitors, hypoglycemia, hypertension

\section{Introduction}

Angiotensin-converting enzyme (ACE) inhibitors are among the most common medications used to treat patients with concomitant hypertension and diabetes. They are considered the first line of treatment for hypertension in this population. ACE inhibitors can improve insulin sensitivity, which can lead to an approximately three- to four-fold increase in the risk of hypoglycemia in patients with diabetes, especially those receiving other hypoglycemic agents, in particular, sulfonylureas. In contrast, treatment with angiotensin receptor blockers is not associated with an increased risk of hypoglycemia. To our knowledge, ACE inhibitors have not been reported to induce hypoglycemia in patients without diabetes [1-7]. This report describes a patient without diabetes experiencing recurrent severe hypoglycemia induced by the ACE inhibitor lisinopril.

Received 08/14/2019

Review began 08/16/2019 Review ended 08/19/2019 Published 08/21/2019

\section{(C) Copyright 2019}

Elshimy et al. This is an open access article distributed under the terms of the Creative Commons Attribution License CC-BY 3.0., which permits unrestricted use, distribution, and reproduction in any medium, provided the original author and source are credited.

\section{Case Presentation}

A 76-year-old woman with a past medical history of hypertension and no prior history of diabetes who was being treated with lisinopril presented to the ED with an abrupt onset of dysarthria and confusion. She was found to have hypoglycemia (blood glucose, $25 \mathrm{mg} / \mathrm{dL}$ ), which responded to intravenous administration of $50 \mathrm{~mL}$ of $50 \%$ dextrose, with complete resolution of her symptoms. However, hypoglycemia recurred in less than one hour, and she was started on a $10 \%$ dextrose drip. Abdominal MRI showed a cystic pancreatic lesion around $1.1 \mathrm{~cm}$ in diameter, which was confirmed by endoscopic ultrasound (Figure 1). 


\section{Cureus}

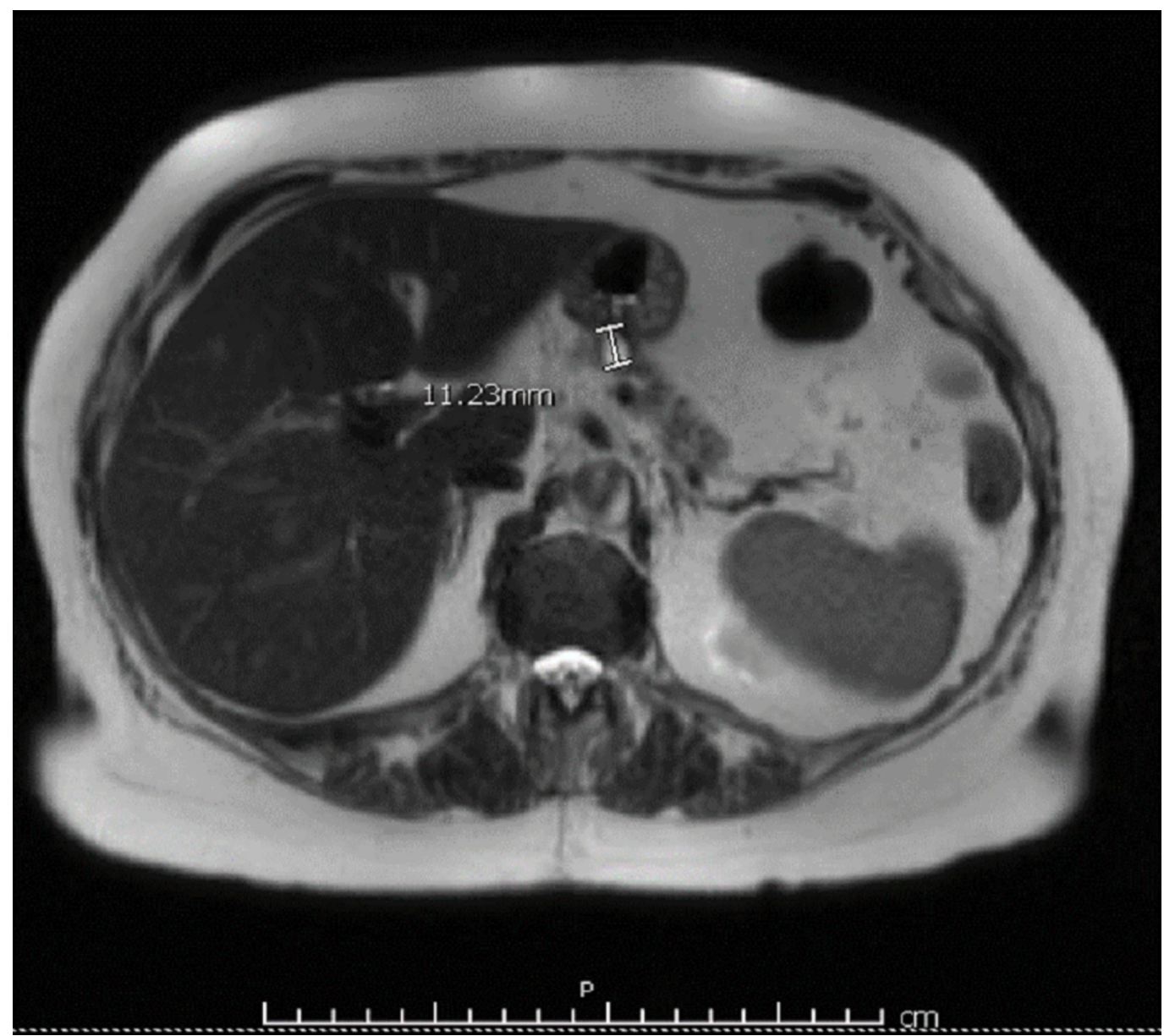

FIGURE 1: Abdominal MRI with and without contrast showing a 1.1-cm cystic lesion in the body of the pancreas without internal enhancement or septations.

The results of all other tests were within normal ranges, including high dose cosyntropin (250 $\mu \mathrm{g})$ stimulation test, hemoglobin A1C concentration, and thyroid, kidney, and liver function tests (Table 1).

Cortisol level at baseline

Cortisol level 30 min after receiving cosyntropin

Cortisol level 60 min after receiving cosyntropin
$11.4 \mu \mathrm{g} / \mathrm{dL}$

$21.9 \mu \mathrm{g} / \mathrm{dL}$

$25.0 \mu \mathrm{g} / \mathrm{dL}$

TABLE 1: Normal results of cosyntropin (synthetic ACTH) stimulation test, following intravenous injection of a standard dose $(250 \mu \mathrm{g})$ at baseline.

ACTH, adrenocorticotropic hormone.

The patient was discharged but was readmitted a few days later with recurrent hypoglycemia. A 


\section{Cureus}

72-h fasting glucose test showed noninsulin-mediated hypoglycemia, with a blood glucose concentration of $51 \mathrm{mg} / \mathrm{dL}$ that occurred only after $10 \mathrm{~h}$ of fasting. Other tests showed an insulin concentration of $2 \mathrm{IU} / \mathrm{mL}$, a c-peptide concentration of $0.7 \mathrm{ng} / \mathrm{mL}$, a proinsulin concentration $<7.5 \mathrm{pmol} / \mathrm{L}$, an anti-insulin antibody concentration $<0.4 \mathrm{uU} / \mathrm{mL}$, negative results on a urine sulfonylurea screening test, and an elevated beta-hydroxybutyrate concentration of $23.4 \mathrm{mmol} / \mathrm{L}$ (Table 2).

Factor

Blood glucose

Beta-hydroxybutyrate

C-peptide

Proinsulin

Insulin

Insulin Ab

Human growth hormone

\section{Concentration}

$51 \mathrm{mg} / \mathrm{dL}$

$23.4 \mathrm{mg} / \mathrm{dL}$ (normal, $\leq 2.8 \mathrm{mg} / \mathrm{dL}$ )

$0.7 \mathrm{ng} / \mathrm{mL}$ (normal, $1.1-4.4 \mathrm{ng} / \mathrm{mL}$ )

$<7.5 \mathrm{pmol} / \mathrm{L}$ (normal, $\leq 18.8 \mathrm{pmol} / \mathrm{L}$ )

2 ulU/mL (normal, 2-25 $\mu \mathrm{lU} / \mathrm{mL}$ )

$<0.4 \mathrm{U} / \mathrm{mL}$ (normal, $<0.4 \mathrm{U} / \mathrm{mL}$ )

$0.8 \mathrm{ng} / \mathrm{mL}$ (normal, $\leq 7.9 \mathrm{ng} / \mathrm{mL}$ )

TABLE 2: Serum concentrations of various factors following a $72-\mathrm{h}$ fasting test performed during the patient's second hospitalization.

Because she required a continuous $10 \%$ dextrose drip for a few days, the patient was started on diazoxide to control her blood glucose concentration. However, she developed deep venous thrombosis three days later, which led to discontinuation of diazoxide. Because she was admitted multiple times for recurrent hypoglycemia over three weeks, other causes of hypoglycemia were investigated (Figures 2-5).

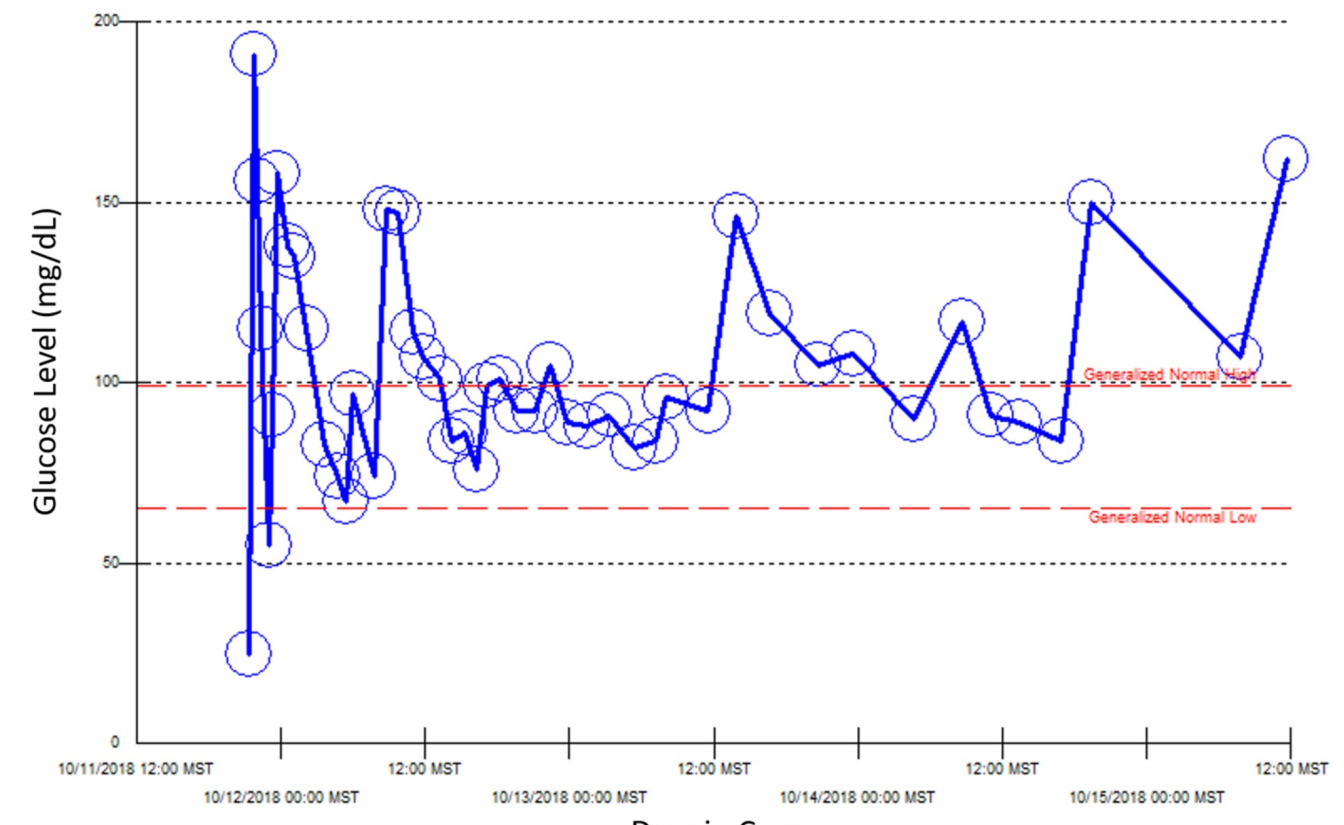

Days in Care 


\section{Cureus}

FIGURE 2: Point of care blood glucose reading during the patient's first hospital admission, October 11-15, 2018.

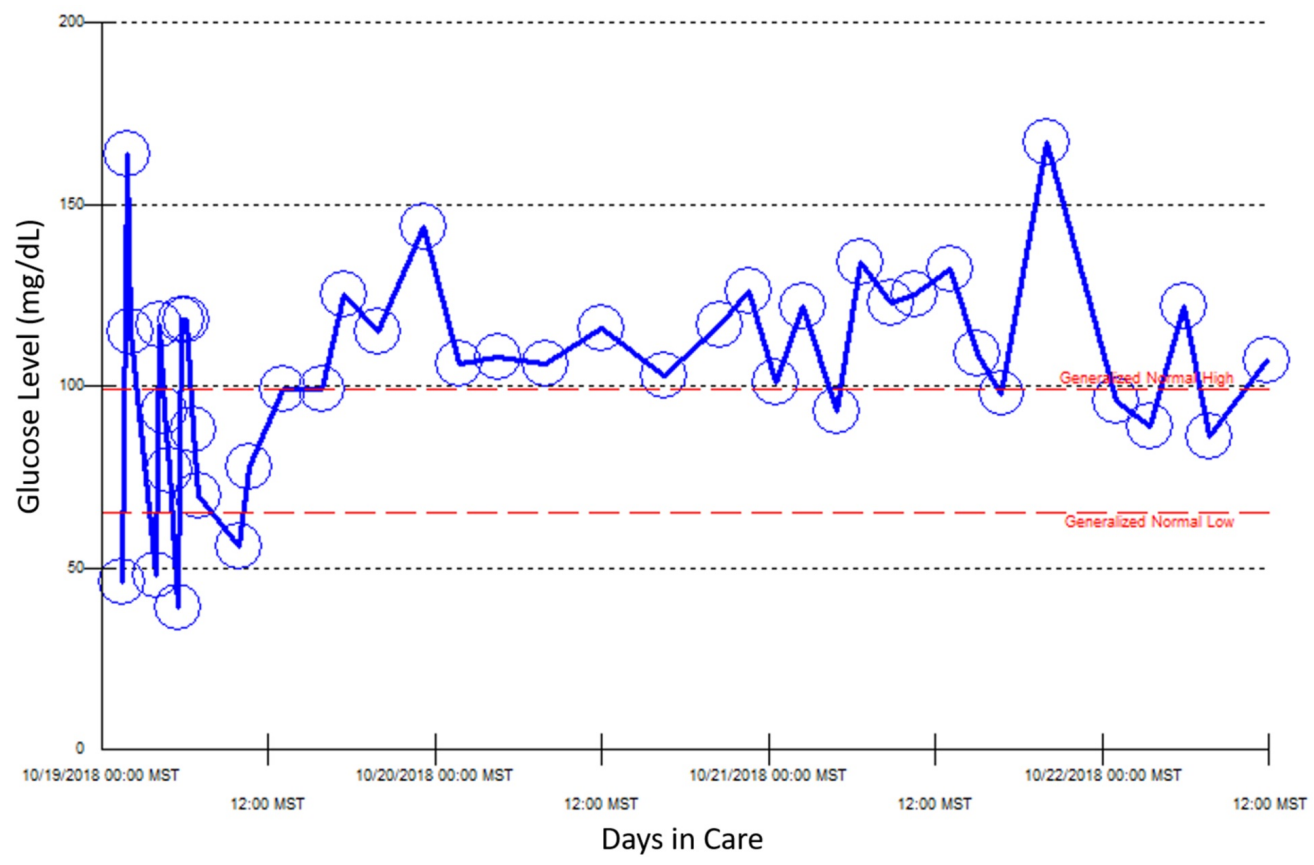

FIGURE 3: Point of care blood glucose reading during the patient's second hospital admission, October 19-22, 2018.

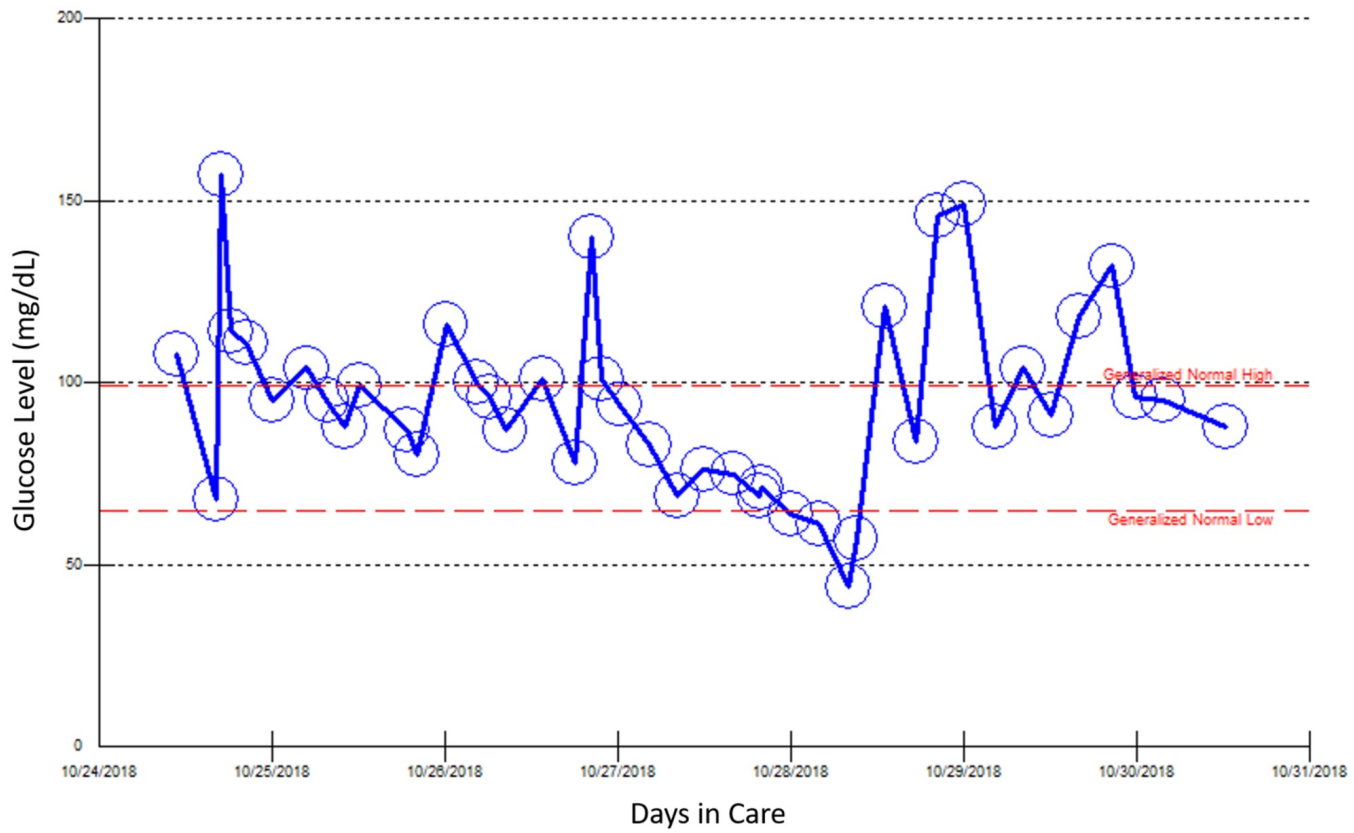

FIGURE 4: Point of care blood glucose reading during the patient's third hospital admission, October 24-30, 2018. At this 


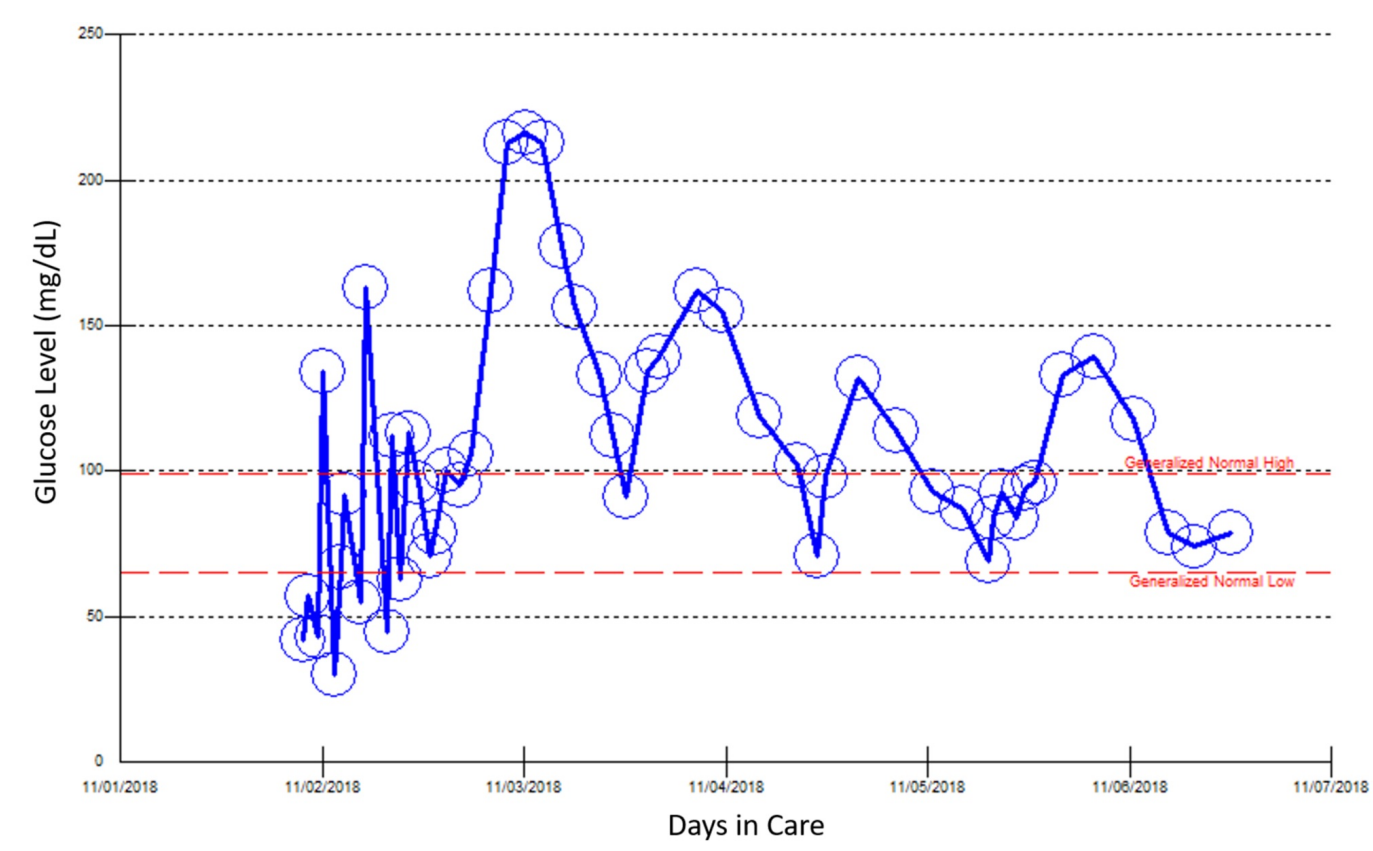

FIGURE 5: Point of care blood glucose reading during the patient's fourth hospital admission, November 1-6, 2018.

A review showed that these episodes of hypoglycemia only occurred two weeks after her dose of lisinopril was increased from $10 \mathrm{mg}$ to $20 \mathrm{mg}$ for her uncontrolled hypertension. Lisinopril was discontinued, and the patient started on treatment with losartan. Monitoring of her blood glucose concentration showed that no additional episodes of hypoglycemia occurred after discontinuation of lisinopril.

\section{Discussion}

Hypoglycemia is defined as a serum blood glucose level concentration $<70 \mathrm{mg} / \mathrm{dL}$ accompanied by the Whipple triad. Symptoms of hypoglycemia may be mild (adrenergic symptoms) or worrisome (neuroglycopenic symptoms, including seizures), with the intensity of symptoms often being directly related to the level of hypoglycemia. The etiology of hypoglycemic events in patients with diabetes is usually related to the treatment of diabetes, such as overly high doses of insulin or a sulfonylurea. These episodes are considered nonalarming as patients can be treated quickly. The etiology of recurrent hypoglycemia in a patient without diabetes, however, is unclear, often requiring extensive patient workup. Causes of hypoglycemia in patients without diabetes may be as simple as adrenal insufficiency or as rare as endocrine neoplasia such as insulinoma [6, 8-10].

The ACE inhibitors are antihypertensive agents commonly used to lower blood pressure in both patients with and without diabetes. These agents reduce angiotensin II levels, resulting in blood pressure reductions due to the relaxation of efferent vessels of the glomeruli, lowering glomerular pressure and decreasing proteinuria, thereby reducing the likelihood of diabetic 
nephropathy. The ACE inhibitors also alter expression of the hormone bradykinin, which has been shown to have a tussive-effect through the kininogen-kinin system, leading to cough as a side effect, an etiology associated with hypoglycemia [6-10].

The ACE inhibitor captopril was first reported in 1985 to induce hypoglycemia in four hypertensive patients, three with insulin-dependent diabetes and one with noninsulin dependent diabetes [5]. Although the exact mechanism by which ACE inhibitors induce hypoglycemia remains unclear, these agents are thought to indirectly increase insulin sensitivity by increasing the levels of circulating kinins which, in turn, leads to increased glucose uptake by muscle tissue through a vasodilatation effect and also downregulate hepatic glucose production [3, 5]. A case report in 1986 described two patients with diabetes who required reductions in their dose of insulin or hypoglycemic agents after treatment with enalapril for hypertension [6]. Captopril treatment of two additional patients with noninsulindependent diabetes resulted in hypoglycemia [7]. Experimental studies suggested that muscle response to insulin is increased in rats with streptozotocin-induced diabetes and in patients with noninsulin-dependent diabetes, suggesting that ACE inhibitors reduce glucose concentrations by elevating systemic kinin levels [9]. In 1997, a patient with diabetes experienced alacepril-induced hypoglycemia complicated by nephropathy, with hypoglycemia in this patient correlating with the use of ACE inhibitors and impaired kidney function [11].

The binding of bradykinin to bradykinin type 2 receptors may have a direct effect on insulinmediated glucose absorption in the body. Bradykinin-induced reductions in angiotensin II concentrations may also blunt sympatho-adrenergic responses to insulin [3, 12-13]. To date, the exact mechanism by which ACE inhibitors induce hypoglycemia remains unclear.

Our patient underwent extensive testing to rule out all other possible causes of hypoglycemia, such as adrenal insufficiency and IGF-2 producing tumors, with insulin-mediated processes ruled out by 72-h fasting. Hypoglycemia in this patient disappeared after discontinuation of the ACE inhibitor, confirming the diagnosis of lisinopril-induced severe hypoglycemia.

Hypoglycemia in this patient was likely due to increased insulin sensitivity, but the exact mechanism remains incompletely understood, emphasizing the need for further investigations in animal models.

\section{Conclusions}

Hypoglycemia is a very rare side effect of ACE inhibitors in patients without diabetes. The results of the present study indicate that patients without diabetes may experience ACE inhibitor-induced hypoglycemia, which responds to discontinuation of the medication as in our patient. Patient medications should be reviewed periodically when managing hypoglycemia.

\section{Additional Information}

\section{Disclosures}

Human subjects: Consent was obtained by all participants in this study. Conflicts of interest: In compliance with the ICMJE uniform disclosure form, all authors declare the following:

Payment/services info: All authors have declared that no financial support was received from any organization for the submitted work. Financial relationships: All authors have declared that they have no financial relationships at present or within the previous three years with any organizations that might have an interest in the submitted work. Other relationships: All authors have declared that there are no other relationships or activities that could appear to have influenced the submitted work.

\section{References}


1. Grégoire F, Pariente A, Fourrier-Reglat A, Haramburu F, Bégaud B, Moore N: A signal of increased risk of hypoglycaemia with angiotensin receptor blockers caused by confounding. Br J Clin Pharmacol. 2008, 66:142-145. 10.1111/j.1365-2125.2008.03176.x

2. Washio M, Onoyama K, Makita Y, Fujishima M, Fujimi S: Hypoglycemia associated with the administration of angiotensin-converting enzyme inhibitor in a diabetic hemodialysis patient. Nephron. 1991, 59:341-342. 10.1159/000186585

3. Morris AD, Boyle DI, McMahon AD, et al.: ACE inhibitor use is associated with hospitalization for severe hypoglycemia in patients with diabetes. Diabetes Care. 1997, 20:1363-1367. 10.2337/diacare.20.9.1363

4. Herings RMC, de Boer A, Leufkens HGM, Porsius A, Stricker BHC: Hypoglycaemia associated with use of inhibitors of angiotensin converting enzyme. Lancet. 1995, 345:1195-1198. 10.1016/s0140-6736(95)91988-0

5. Ferriere M, Lachkar H, Richard JL, Bringer J, Orsetti A, Mirouze J: Captopril and insulin sensitivity. Ann Intern Med. 1985, 102:134-135. 10.7326/0003-4819-102-1-134_3

6. McMurray J, Fraser DM: Captopril, enalapril, and blood glucose . Lancet. 1986, 327:1035. 10.1016/s0140-6736(86)91304-8

7. Rett K, Wicklmayr M, Dietze GJ: Hypoglycemia in hypertensive diabetic patients treated with sulfonylurea, biguanides, and captopril. N Engl J Med. 1988, 319:1609.

8. Cryer PE, Axelrod L, Grossman AB, Heller SR, Montori VM, Seaquist ER, Service FJ: Endocrine Society: evaluation and management of adult hypoglycemic disorders: an Endocrine Society Clinical Practice Guideline. J Clin Endocrinol Metab. 2009, 94:709-728. 10.1210/jc.2008-1410

9. Rett K, Jauch KW, Wicklmayr M, Dietze G, Fink E, Mehnert H: Angiotensin converting enzyme inhibitors in diabetes: experimental and human experience. Postgrad Med J. 1986, 62:59-64.

10. Berne C: Metabolic effect of ACE inhibitors. J Intern Med Suppl. 1991, 229:119-125.

11. Sakaguchi H, Maeda S, Fukunaga Y, Inoue D, Koshiyama H: Hypoglycemia associated with the administration of angiotensin-converting enzyme inhibitor in a patient with diabetes mellitus. Intern Med. 1997, 36:77. 10.2169/internalmedicine.36.77

12. Madsen BK, Hølmer P, Ibsen H, Christensen NJ: The influence of captopril on the epinephrine response to insulin-induced hypoglycemia in humans. The interaction between the reninangiotensin system and the sympathetic nervous system. Am J Hypertens. 1992, 5:361-365. 10.1093/ajh/5.6.361

13. Duka I, Shenouda S, Johns C, Kintsurashvili E, Gavras I, Gavras H: Role of the B2 receptor of bradykinin in insulin sensitivity. Hypertension. 2001, 38:1355-1360. 10.1161/hy1201.096574 